\title{
BUSINESS CAPITAL STRUGTURE AND MANUFACTURING FIRMS PERFORMANCE IN NIGERIA
}

\author{
Olufemi Amos AKINBOLA ${ }^{\mathrm{a} *}$, Abu ZEKERI ${ }^{\mathrm{b}}$, \\ Olugbenga Abiola OJO'
}

a),b), c) Federal University of Agriculture, Department of Business Administration, Abeokuta, Nigeria; Kwara State University, School of Business and Governance, Malete, Nigeria; Leeds Metropolitan University, Faculty of Business and Law, Leeds, United Kingdom

Please cite this article as:

Article History:

Akinbola, O.A., Zekeri, A. and Ojo, O.A. 2018. Received: 28 February 2018 Business Capital Structure and Manufacturing Firms Accepted: 30 July 2018 Performance in Nigeria. Review of Economic Studies and Research Virgil Madgearu, 11(2), pp.5-32. doi: 10.24193/RVM.2018.11.24.

Abstract: This study considered capital structure and manufacturing firms,
performance by examining whether debt or equity as forms of business financing
assist firms to take independent and proper investment decisions that may enhance
corporate performance and financial stability. The study adopted primary data
through the questionnaire and regression analysis was used to test the hypotheses.
The result revealed that both debt and equity have a significant influence on
investment decision of firms. In addition, the combination of both forms offinancing
significantly affects corporate performance. The study obliged organizations to
draw a master plan for financing options to facilitate quality decisions. Key words: debt financing; equity financing; investment decision; corporate performance

JEL Classification: M1; M1O.

(C) 2018 Alma Mater Publishing House. All rights reserved.

* Corresponding author. E-mail address: akinbolaoa@funaab.edu.ng. 


\section{References:}

1. Abor, J., 2005. The effect of capital structure on profitability: an empirical analysis of listed firms in Ghana. Journal of Risk Finance, 6(5), pp. 438-47.

2. Abor, J., Biekpe, N., 2007. Corporate governance, ownership structure and performance of SMEs in Ghana: implications for financing opportunities. Corporate Governance: The international journal of business in society, 7(3), pp. 288-300.

3. Ahmadpour, A., and Yahyazadehfar, M., 2010. Financial Management, Leverage (7th ed.). Mazandaran University, 1.

4. Akintoye, I.R., 2008. Effect of capital structure on firms' performance: the Nigerian experience. European Journal of Economics, Finance and Administrative Sciences, 7(1), pp.233-43.

5. Antoniou, A., Guney, Y. and Paudyal, K., 2002. Determinants of corporate capital structure: Evidence from European countries, University of Durham, working paper.

6. Berle, A.A., and Means, G., 1932. The modern corporation and private property. New York: Macmillam.

7. Booth, L., Aivazian, V., Demirguc-Kunt, A. and Maksimovic, V., 2001. Capital structures in developing countries. The Journal of Finance, 56(2), pp. 87-130.

8. Brealey, R. and Myers, S.C., 2003. Financing and Valuation, Ch. 19, Principles of Corporate Finance, 7 th Edition, London: McGraw Hill.

9. Brigham, E. and Gapenski, L., 1996. Financial Management. Dallas: The Dryden Press.

10. Brockington, R., 1990. Financial Management. London: ELBS.

11. Capon, N., Farley, J.U., Hoenig, S., 1990. Determinants of financial performance: A meta-analysis. Management Science, 3(10), pp.1143-59.

12. Chakraborty, I., 2010. Capital structure in an emerging stock market: The case of India. Research in International Business and Finance, 24(1), pp.295-314.

13. Chiang, Y.H., Chan, P.C.A. and Hui, C.M.E., 2002. Capital structure and profitability of the property and construction sectors in Hong Kong. Journal of Property Investment and Finance, 20(6), pp.434-54.

14. Das, S. and Roy, M., 2007. Inter-Industry Differences in Capital Structure: The Evidence from India. Finance India', The Quarterly Journal of Indian Institute of Finance, 21(2), pp.395-402. 
Akinbola, Zekeri and OJo, Business Capital Structure...

15. D’Mello, R. and Miranda, M., 2010. Long-term debt and over investment agency problem. Journal of Banking \& Finance, 34(2), pp.324-35.

16. Drobetz, W. and Fix, R., 2003. What are the Determinants of the Capital Structure? Some Evidence for Switzerland. Working paper, 88.

17. Ebaid, E.I., 2009. The impact of capital-structure choice on firm performance: empirical evidence from Egypt. The Journal of Risk Finance, 10(5), pp.477-87.

18. Elliot, B. and Elliot, J., 2002. Financial Accounting and Reporting. 12th Edition, London: Prentice Hall/Financial Times.

19. Eriotis, N.P., Franguoli, Z. and Neokosmides, Z.V., 2002. Profit Margin and Capital Structure: An Empirical Relationship. The Journal of Applied Business Research, 18(2), pp.85-89.

20. Fama, E.F. and French, K.R., 2002. Testing Tradeoff and Pecking Order Predictions about Dividends and Debt. Review of Financial Studies 15(Spring 2002), pp. 1-33.

21. Fama, E. and Jensen, M., 1983. Separation of Ownership and Control. Journal of Law and Economics, 26(2), pp.301-25.

22. Hung, C.Y., Albert, C.P.C. and Eddie, H.C., 2002. Capital structure and profitability of the property and construction sectors in Hong Kong. Journal of Property Investment and Finance, 20(2), pp. 434-53.

23. Jensen, M.C., 1983. Organization Theory and Methodology. Accounting Review, 58(1), pp.319-39.

24. Jensen, M., 1986. Agency Costs of Free Cash Flow, Corporate Finance, and Takeovers. American Economic Review, 76(2), pp. 323-29.

25. Jensen, M.C. and Meckling, W.H., 1976. Theory of firm: Managerial behavior, Agency costs and capital, Journal of Financial Eonometrics, 3(1), pp.306-65.

26. Jensen, M. and Ruback, R., 1983. The market for corporate control: The Scientific Evidence. Journal of Financial Economics, 11(2), pp.5-50.

27. Kochhar, R., 1997. Strategic assets, Capital Structure, and Firm Performance. Journal of Financial and Strategy Decisions, 10(3), pp.23-36.

28. Kyereboah-Coleman, A. (2007), The impact of capital structure on the performance of microfinance institutions. Journal of Risk Finance, 8(1), pp.56-71.

29. Majumdar, S.K. and Chhibber, P., 1999. Capital structure and performance: evidence from a transition economy on an aspect of corporate governance. Public Choice, 98(3), pp. 287-305. 
Review of Economic Studies and Research Virgil Madgearu, 2018, 11(2)

30. Margaritis, D. and Psillaki, M., 2010. Capital structure, equity ownership and firm performance. Journal of Banking \& Finance, 34(3), pp. 621-32.

31. Modigliani, F. and Miller, M.H., 1958. The Cost of Capital, Corporation Finance and the Theory of Investment. The American Economic Review, 48(3), pp. 261-97.

32. Modigliani, F. and Miller, M., 1963. Corporate income taxes and the cost of capital correction. American Economic Review, 53(3), pp. 433-43.

33. Myers, S. and Majluf, N., 1984. Corporate Financing and Investment Decisions when Firms Have Information that Investors do not Have. Journal of Financial Economics, 13(2), pp.187-221.

34. Mramor, D. and Crnigoj, M., 2009. Determinants of Capital Structure in Emerging European Economies: Evidence from Slovenian Firms. Emerging Markets Finance and Trade, 47(1), pp. 72-89.

35. Onaolapo, A.A., Kajola, S.O., 2010. Capital Structure and Firm Performance: Evidence from Nigeria. European Journal of Economics, Finance and Administrative Sciences, 25(1), pp. 70-82.

36. Pratheepkanth, P., 2011. Capital Structure and Financial Performance: Evidence from Selected Business Companies in Colombo Stock Exchange, Sri Lanka. Journal of Arts, Science and Commerce, 2(2), pp.171-83.

37. Rajan, R.G. and Zingales, L., 1995. What do we know about capital structure? Some evidence from international data. The Journal of Finance, 50(5), pp.1421-6o.

38. Ramachandra, V.S., Rao, S. and Nageswara, V.D., 2008. Capital Structure, Industry Pricing, and Firm Performance, 21st Australasian Finance and Banking Conference Paper.

39. Remmers, L., Stonehill, A., Wright, R. and Beekhuessen, T., 1974. Industry and Size as Debt Ratio Determinants in Manufacturing Internationally. Financial Management, 3(2), pp.24-32.

40. Saad, N.M., 2010. Corporate Governance Compliance and the Effects to capital Structure. International Journal of Economics and Financial, 2(1), pp.105-14.

41. San, O.T. and Heng, T.B., 2011. Capital Structure and Corporate Performance of Malaysian Construction Sector. International Journal of Humanities and Social Science, 1(2), pp. 28-36.

42. Scott, D.F.,Jr. and Martin, J.D., 1975. Industry Influence on Financial Structure. Financial Management, 4(1), pp. 67-73. 
43. Spanos, Y.E., Zaralis, G. and Lioukas, S., 2004. Strategy and industry effects on profitability: Evidence from Greece. Strategic Management Journal, 25(2), pp. 139-65.

44. Titman, S., 1984. The effect of capital structure on a firm's liquidation decision. Journal of Financial Economics, 13(1), pp. 137-51. doi:10.1016/0304-405x(84)90035-7.

45. Titman, S. and Grinblatt, M., 1998. Financial Markets and Corporate Strategy. McGraw-Hill, Inc.

46. Warokka, A., Herrera, J., Abdullah, H., 2011. East Asian corporate governance: a test of the relation between capital structure and firm performance. International Journal of Economics and Finance Studies, 3(2), pp.1-10.

47. Yamane, T., 1967. Statistics, An Introductory Analysis, 2nd ed., New York: Harper and Row.

48. Zeitun, R. and Tian, G.G., 2007. Capital structure and corporate performance: evidence from Jordan. Australasian Accounting, Business \& Finance Journal, 1(4), pp.40-61. 